\title{
Evaluation of Landscape Natural Values in Tourism, with Special Regard to Vegetation - Case Study: Otwock Commune, Central Poland
}

\author{
Beata Elżbieta Fornal-Pieniak*, Barbara Żarska \\ Institute of Horticultural Sciences, Department of Environmental Protection and Dendrology, \\ Warsaw University of Life Sciences - SGGW, Nowoursynowska 166, 02-787 Warszawa, Poland
}

Received: 19 January 2021

Accepted: 17 July 2021

\begin{abstract}
Landscape and tourism attractiveness are very much related with each other. The evaluation of natural resources of landscape is a basic environmental research method useful for environmental modeling, landscape planning and tourism development. Vegetation is an important landscape natural resource (a component of environment) having a great meaning including tourism. The aim is to present the original methodic approach to evaluation of landscape natural values, with special regard to vegetation using its high indicative environmental value, for needs of tourism aspect at local level o planning. This methodic approach has been implemented and tested in Otwock commune area, central Poland, the European Lowland. The assessment took place in several stages: field research, division of the studied area into spatial-landscape units, mapping of vegetation and other distinguishing natural elements, selection of criteria of assessment and system of evaluation, conducting the assessment, classification of landscape values into categories and formulating guidelines to management including tourist use. The criteria used in the assessment were selected in consideration of landscape components with emphasis on vegetation, as well as elements connected with tourist attractiveness. The following criteria were used in landscape evaluation: occurrence of natural protected areas, occurrence of natural protected objects, degree of vegetation naturalness, vegetation resistance to recreational use, vegetation attractiveness for tourists, diversity of vegetation, occurrence of surface water, diversity of terrain relief. Values of vegetation/landscape have been proven and four value categories of terrains distinguished in tourist aspect. The results have shown that presented approach to landscape evaluation, with using vegetation indicative role in the context of the whole landscape, is relatively simple and may be helpful for various decisions of local governments concerning tourist use and other functions. The originality of this approach lies in giving more
\end{abstract}

*e-mail: beata_fornal_pieniak@sggw.edu.pl 
importance to vegetation in assessing the overall landscape. It may be convenient in cases, where values of inanimate nature are not highly spectacular and/or information on vegetation is more detailed and also if commune authorities want to do the study on their own, with a limited number of experts. It has been shown what and how to use possible evaluation criteria in practical application with certain available landscape resources. The criteria used in the assessment are very universal, especially in areas of rich vegetation, as Otwock commune is. The assessment method and results were understandable to a wide range of officials and specialists in Otwock. The results confirmed high quality of natural values in tourist aspect in the study area. The presented evaluation is relatively simple and useful approach for landscape planning including tourism in Poland and also in other countries in Central Europe.

Keywords: landscape assessment, vegetation assessment, tourism, landscape natural resources, ecosystem services

\section{Introduction}

Tourist attractiveness of areas is strictly correlated with the quality of natural and cultural values [1-3]. There is an association between cultural services and specific ecosystem and land cover types. It means that ecosystems also provide certain cultural services to tourists and locals (cultural ecosystem services) [4]. Natural features of an area influence the cultural specificity of the region, especially visible in rural areas [5].

Tourism is a very important sector of economy and great stimulator of development. A large part of the global income has been generated by widely understood tourist sector. Travel and tourism contribution to the world's economy was 10,4\% of global GDP in 2018 and $9,9 \%$ of total employment (data from the period before the Covid-19 pandemic) [6], therefore tourism is the important aspect of human well-being.

Identification and assessment of natural resources should be included in the strategy of ecosystem services $[4,7,8]$. Tourism development is addressed especially to regional and local governments. Landscape values, including natural values, according to the Nature Conservation Act 2004 [9], mean "ecological, aesthetic or cultural values of the area and related terrain, creations and components of nature, shaped by the forces of nature and/or human activity". Tourist values (natural and not-natural ones) are specific elements and features of the geographic environment or specific manifestations of human activity attracting tourists $[10,11]$. World Tourism Organization (UNWTO) described tourism as "a social, cultural and economic phenomenon which entails the movement of people to countries or places outside their usual environment for personal or business/professional purposes". Tourism aims are: use the environment, get to know and explore the world, providing relaxation, didactics and general human development [10, 12].

The landscape resources primarily affect the development of tourism in a given region. The term "landscape", according to the European Landscape Convention [13], means an area perceived by people, the character of which is the result of the action

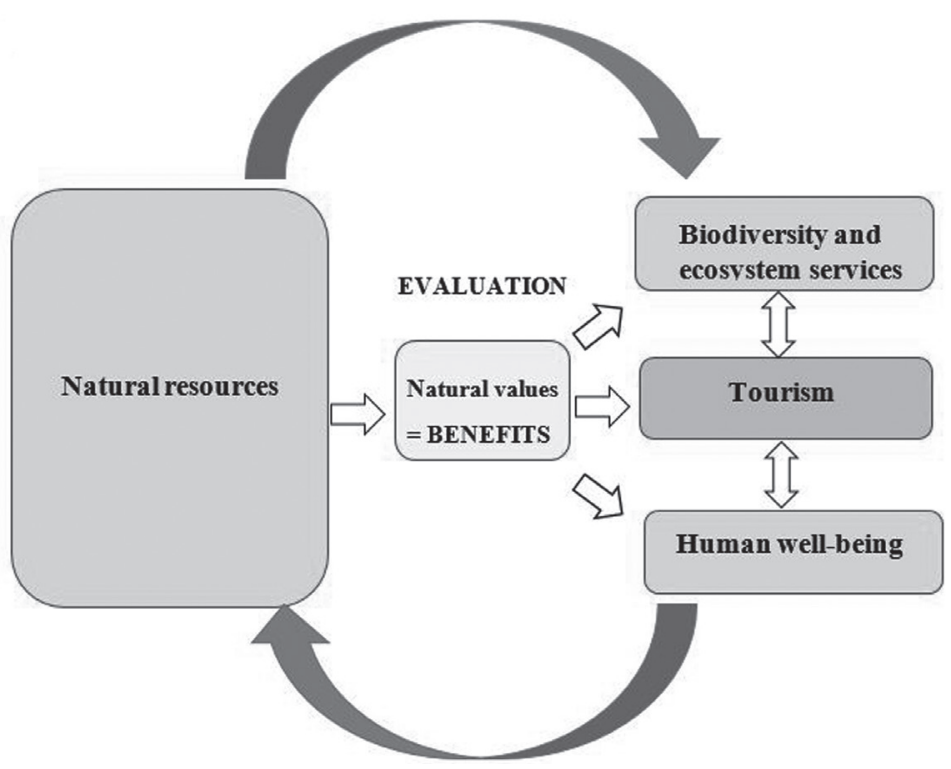

Fig.1. An idea of framework: the relationship between natural resources, ecosystem services, tourism and human well-being (original). 
and interaction of natural and/or human factors". However, according to Tribot, Deter and Mouquet [14], landscape is the whole of nature together with elements introduced by man on a naturally limited section of the Earth, assessed as a set of natural conditions representing specific external aesthetic and scenic features. Depending on the intensity of anthropogenic transformations, the following types of landscapes can be distinguished [14] (this classification seems to be still valid): a) primary - not transformed by man, shaped by natural processes, b) natural - with the dominance of natural elements, with little human interference, c) cultural - transformed by anthropogenic factors, while maintaining the basic structure of nature, d) degraded - heavily transformed by man, with a disturbance of the natural structure and low aesthetic values, e) devastated - strongly transformed and destroyed, with the disappearance of natural elements.

The landscape is assessed for tourism regarding various components, including natural resources being an essential contents. The research shows that natural values of landscape are generally highly estimated by tourists [15-17], often in the first place before cultural values. The occurrence of natural protected areas of high range (national parks, nature reserve, landscape parks, lately Nature 2000 sites) is a kind of magnet for tourists [18]. Evaluation is a basic environmental research method very useful for needs of landscape planning, mapping, environmental modeling and tourism development [19, 20] (Fig. 1).

Natural evaluation is the assessment of landscape natural values, as well as "estimation and classification of complex goods of nature or products of human work, and their relationship" $[15,21]$. Its purpose is to assess the analyzed elements and indicate areas of different landscape value. The quality of landscape is influenced by both natural and anthropogenic (man-made) elements $[22,23]$.

There are several possible ways to assess landscape resources. The criteria and way of evaluation (assumed in research) depend on the purpose of assessment, specificity of landscape in a study area and scale of elaboration. The types of approach can be divided into two groups: methods based on assessing the natural quality of areas and methods evaluating the economic usefulness of areas. However, the first stage of action should be recognition and assessment of natural environment/landscape features/values, what is one of the basis for economic analysis. The criteria of assessment depend on the aim of evaluation. If the purpose is nature/landscape protection, the assessment is oriented to natural values recognition. If the aim is to determine suitability and attractiveness for tourism, criteria of assessment are targeted to natural and cultural values recognition and attractiveness for tourists, regarding sensitivity of ecosystems and wild species to tourist use. In natural evaluation of areas following criteria are frequently used around the world (indicated order: inanimate nature features, animate nature features) $[19,24,25]$ : terrain relief diversity, occurrence of specific/spectacular forms of terrain relief, occurrence of surface water, naturalness extent of vegetation cover, flora and fauna species richness, occurrence of rare/protective species of flora and fauna, size of area occupied by natural/seminatural ecosystems, diversity of ecosystems/ecological structure of landscape, uniqueness of natural elements (local, regional, national, international). Among the most important methods generally concerning the whole landscape evaluation, are: the SBE method Scenic Beauty Estimation [26] (accent put on visual aspect), the method of architectural/ landscape units and interiors (called JARK-WAK method; accent put on natural, cultural and visual aspects) [27], method of Wejchert's curve of impressions (accent on visual aspect) [28], method of assessing the significance of a landscape dominant (accent on cultural, natural and visual aspects) [29], method of landscape perceptual analysis (accent on visual, cultural and natural aspects) [30], method of assessing the state of cultural values of rural landscape /rural settlements (accent on visual, cultural and natural aspects) [31]. It is worth noting that these methods have been developed also for tourism purposes.

Tourism, with many advantages (e.g., recreational, educational and economic benefits), can also cause negative effects: degradation of natural resources. The relationship between tourism and the environment is very complex. Tourism can have negative effects on nature, which are determined primarily by the destructive action of tourist facilities (for example degradation of soils and vegetation) because of building new tourism infrastructure) and directly by tourists, with wider effects on the environment and its components, in particular tourism resources. Tourism contributes to environmental degradation in many aspects: environment's transformation as consumption of various resources, pressure exerted through overload, conflict, pollution, devastation of natural resources [32].

The vegetation generally comes first in terms of sensitivity and exposure to degradation. Intensive use of vegetation have got impact on reduction of benefits of biodiversity and ecosystem services [33]. It is connected with resistance and resilience of vegetation for trampling [34-36]. Trampling has got a lot of negative effects on vegetation and the scale of damage depends on life forms of plants [34].

Proper management of natural resources, including legally protected sites, gives a real chance to keep biodiversity in cities and rural areas [37], that also benefits for tourism aspect [38]. The research shows, that the less transformed landscape, the more attractive it becomes to tourists [20].

The assessment of the natural resources is important for the purposes of landscape planning and tourism development. The actions of the local authorities should focus on supporting local communities in a variety of ways: financial, substantive, promotional etc. [17, 18]. 
On the other hand, participation of local community in landscape planning, protection and management is necessary [39] to create it efficiently keeping sustainability in land use [40, 41]. Every administrative district, also at local level (e.g., commune), should take into account tourist function development; even in those areas, that have not a lot of tourist values and are located outside of main tourist regions. In case of areas with different dominant function (e.g., agriculture - in rural communes), tourism is a perfect supplement, as regards business diversification and raising funds for maintenance and good life conditions of local population. Tourist function in a commune area may be: a) dominant function - next to, for example, forest function, b) one of several equivalent functions, c) supplement function - in case of shortage of tourist values. Worth noticing, areas with predominating agricultural role have a very good chance to develop specific forms of tourism (e.g., agrotourism, eco-tourism, slow tourism) [42-44]. Agritourism should be an important factor of sustainable development, including improvement of living conditions in rural settlements and increase of local biodiversity as a point of interest for tourists [45-47]. A variety of cultural heritage in rural areas, strictly related with the specificity of natural environment, is also a magnet for tourists, so folklore and historic rural landscape should be protected during land-use changes [48-50]. Nowadays, there is a trend for rural style of living, being near nature and living in harmony with nature. This is evidenced by the described in literature case studies and models of sustainable development and tourism in rural areas [e.g., 51-53] When developing tourism, it is necessary to keep permanently good state of natural values in an area. It helps to maintain the high quality of biodiversity and ecosystem services and leads to sustainable development, including climate change adaptation [54, 55]. Of course, the realization of sustainable tourist function is necessary, including protected areas [56-58]. The permanent problem is to achieve and maintain the balance between nature protection and use intensity, as well as between nature and culture, called sometimes "use-preservation paradox" [59].

The aim is to present the original methodic approach to landscape natural values evaluation in terms of tourism, partly different than usually taken, with special regard to vegetation using its high indicative environmental value in the context of the whole landscape. Such combination of evaluation criteria has been not presented yet. The set of assumed criteria helps to correlate tourist use with high biological diversity. Such method may be appropriate and convenient in areas, where values of inanimate nature are not highly spectacular or information/research on vegetation is detailed and if commune authorities want to do the study on their own, with a limited number of experts. This methodical approach has been implemented and tested at local level - case study of Otwock commune, central Poland, European Lowland.

\section{Study Area and Methods}

The study area - Otwock commune is located in the central part of the Masovian Voivodeship at the distance about $25 \mathrm{~km}$ in south-eastern direction from Warsaw - capital of Poland, in Central European Lowland (Fig. 2). The Otwock commune has the area of $47 \mathrm{~km}^{2}$ and population about 44000 . Nowadays, Otwock is an urban commune of special character, because forests cover around 45\% (mainly pine forests) and agricultural lands $29 \%$ of total area. Health service is highly-developed due to the past function of the spa and present climatic values. Agriculture there is not intensive and generally accordant with natural potential of the area (close to organic, sustainable agriculture). The agricultural landscape of Otwock commune is the mosaic of small-sized fields and meadows in the vicinity of forests and waters, with a small cast of animals, very picturesque.

Otwock is a forest park-city, with plenty of natural and cultural monuments, with many sanatoriums, villas and summer houses; the last two of them are in unique architectonical style called "Świdermajer" (many cultural monuments of wooden building from XIX and beginning of XX centuries). Otwock received city rights in 1916. In 1923-1939 (before the World War II) Otwock was considered as a health resort because of healing properties of climate. Today Otwock is an important administrative, service (especially health treatment), therapeutic and recreational center near Warsaw [60, 61].

In terms of geography and nature, Otwock commune is located mainly in the lower Vistula River valley (on the right bank of the Vistula River, on flooded and upper terraces of the valley), on the borderland with two physico-geographical mesoregions: Środkowomazowiecka Lowland and Garwolińska Plateau.

In Otwock commune there are 3 nature reserves: the "Świder River" Reserve (partly in the study area), "Pogorzelski Mszar" Reserve and "Świderskie Islands" Reserve (partly in). The commune is located between two parts of the Mazowiecki Landscape Park (partly within its borders). The northern fragment of the study area is in the Warsaw Area of Protected Landscape. Two areas of Nature 2000 partly occur in Otwock commune: PLB 140004 Dolina Środkowej Wisły [PLB Middle Vistula River Valley] and PLH 140025 Dolina Środkowego Świdra [PLH Middle Świder River Valley]. Forests in Otwock commune belong to large remnants of Osieck Primeval Forest [61]. Important water elements of landscape are: the Vistula River (the biggest river in Poland, almost natural character) and the Świder River (smaller river of natural character being the right tributary of the Vistula) (Fig. 2c)

The extraordinary climatic qualities of pine forests and geothermal water resources had got an impact on building up numerous sanatoriums, hotels, guest houses, summer houses, villas and restaurants in Otwock town 


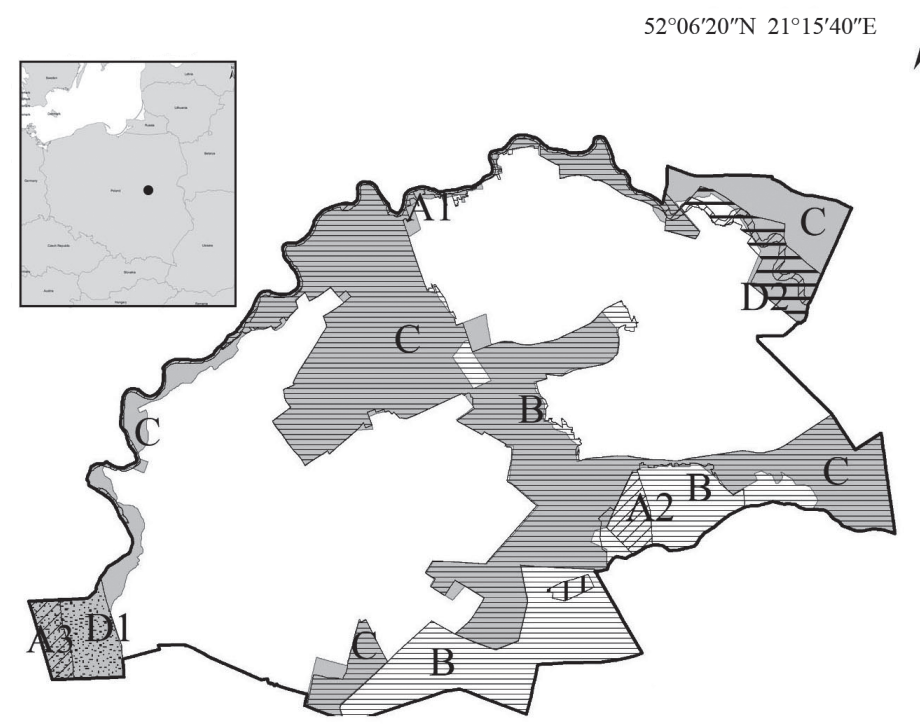

A1 - the Świder River Reserve

A2 - Pogorzelski Mszar Reserve

A3 - the Świderskie Islands Reserve

B - the Mazowiecki Landscape Park

C - the Warsaw Area of Protected Landscape.

D - Areas of Nature 2000:

D1 - PLB 140004 Dolina Srodkowej Wisły (PLB Middle Vistula River Valley)

D2 - PLH 140025 Dolina Środkowego Świdra (PLH Middle Świder River Valley)

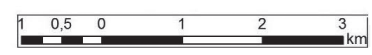

Fig. 2. Location of the study area - Otwock commune in Europe and in Poland, with regard to protected nature areas (own elaboration).

and commune. The existing tourist development is connected with health service treatment (first of all: 5 hospitals and 7 sanatoriums with green areas) and, in open access, tourist offer, among others: Center of Tourist Information PTTK, well-developed network of tourist trails (hiking, biking and horseback trails), 10 objects of accommodation facilities and 15 objects of catering facilities [62]. Nowadays, most of hiking trails are located in forests, along waters and in the city. One canoeing trail is along the Świder River in the northern part of the Otwock commune.

Concerning methodical approach (Fig. 3), the landscape assessment in tourism aspect, with special regard to vegetation, took place in several stages: field research, mapping of vegetation and other distinguishing natural elements/features of landscape, division of the study area into spatial-landscape units (for aims of landscape inventory and analysis), selection of criteria for assessment and system of evaluation (system of awarding points), conducting an assessment, classification of landscape values into categories and formulating guidelines to management including tourist use (with inspiration and modification of approach proposed in [63]). Field research was carried out including types of vegetation, relief of terrain, surface water occurrence and land use, taking into account natural protected areas in the study area - Otwock commune. Types of vegetation were classified according to Władysław Matuszkiewicz [64]. The following stage of work was the division of the study area into spatiallandscape units, distinguishing relatively uniform type of prevailing landscape, on the base of three criteria: relief of terrain and land cover/land use. The next phase of the research was to conduct landscape evaluation with special consideration of vegetation, in reference to tourist attractiveness. The evaluation method was adopted [63], with Authors' modification according to the purpose of research and specificity of the study area. Eight assessment criteria and the scale of scoring from 0 points to 3 points have been used for landscape evaluation ( 0 points - when given landscape feature does not occur). All distinguished spatial-landscape units have been assessed according to assumed criteria.

The following criteria have been applied to assess landscape natural values with special regard to vegetation, in the aspect of tourism (original):

Criterion 1 - occurrence of areas protected under the nature protection law: 0 points - no protected areas; 1 point - one or more protected areas of lower range (e.g. area of protected landscape, ecological site) occupying a small part of the area; 2 points - one or more protected areas of mostly middle rank (e.g. landscape park, Nature 2000 area) covering the most of the area; 3 points - the whole/most of area under 


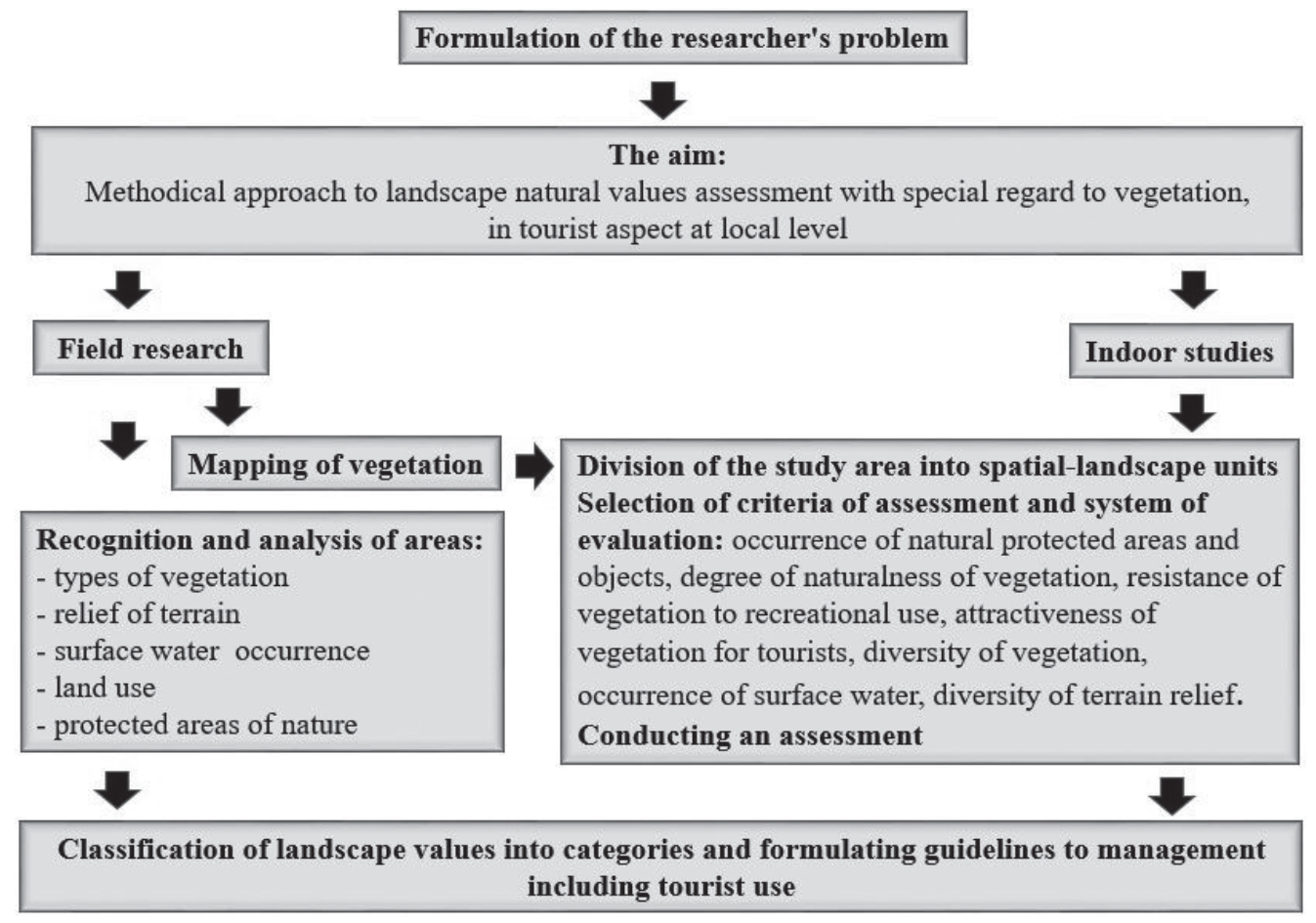

Fig. 3. Methodical approach - scheme (original).

protection of high range (e.g. national park, nature reserves) or more than one protected areas of high and middle range (e.g. national park, nature reserve, landscape park, Nature 2000 area).

Criterion 2 - occurrence of objects protected under the nature protection law: 0 points - no objects; 1 point - 1 object; 2 points $-2-3$ objects; 3 points -4 or more objects (nature monuments, documentation sites of inanimate nature, ecological sites, nature-landscape sites)

Criterion 3 - degree of naturalness of vegetation cover: 1 point - low, 2 points - medium, 3 points - high degree.

Criterion 4 - resistance of vegetation to recreational use: 0 points - very sensitive, 1 point - low, 2 points medium, 3 points - quite resistant and highly resistant.

Criterion 5 - attractiveness of vegetation for tourists: 0 - no vegetation, 1 point - not very attractive, 2 points - medium attractive, 3 points - very attractive (e.g. forests, surface waters).

Criterion 6 - diversity of vegetation: 0 points - no vegetation; 1 point - rather small: mostly synanthropic types of vegetation covering most of the area; 2 points different types of vegetation (natural, semi-natural and synanthropic plant communities) covering most of the area; 3 points - different types of vegetation of mainly natural and semi-natural character covering the whole/ most of the area.

Criterion 7 - occurrence of surface water: 0 points - no surface water in the area and in the vicinity at the distance up to $200 \mathrm{~m}$ from unit borders; 1 point small water courses/water reservoirs are located in the vicinity of the area at the distance up to $200 \mathrm{~m}$; 2 points
- small/medium river/water reservoir is located within the area or in the neighborhood directly at the border; 3 points - medium/large river/water reservoir is located in the area or directly at the border.

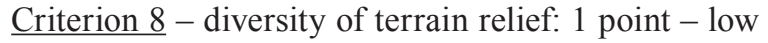
diversity (rather flat area), 2 points - medium diversity (wavy/hilly terrain); 3 points - high diversity with occurrence of specific forms of relief (e.g. river valleys, natural water courses, old river beds, distinctive terrain culminations, scarps, edges, dunes, eskers, kames, rocks, caves, erratic boulders et cetera).

The degree of vegetation naturalness was determined after Władysław Matuszkiewicz [64] distinguishing natural, semi-natural and synanthropic types of vegetation. Resistance of vegetation to recreational use was assessed on the base of plant communities' resistance to trampling according to Alicja Krzymowska-Kostrowicka as well Czesław Wysocki and Peter Sikorski [16, 65] with modification. Krzymowska-Kostrowicka distinguished direct tourist impact on vegetation, e.g., trampling, biking, driving, and indirect impact - among others emission of pollutants.

The Authors of this paper have presented modified approximate characteristics of vegetation usefulness and attractiveness for tourism aspect. It was elaborated for main types of vegetation in Central Europe in the scope: degree of naturalness, resistance of vegetation to direct trampling and tourist attractiveness of vegetation including phenological aspect [16, 65], (Table 1).

According to points scale (assumed within evaluation criteria) and total of points received by spatial-landscape units during landscape evaluation, 
Table 1. Selected types of vegetation, degree of naturalness, vegetation resistance to recreational use and tourist attractiveness representative for lowlands, uplands, mountains and river valleys in Central Europe (own elaboration, with use: [16, 65], modified).

\begin{tabular}{|c|c|c|c|}
\hline Types of vegetation & $\begin{array}{l}\text { Degree of } \\
\text { vegetation } \\
\text { naturalness }\end{array}$ & Vegetation resistance to recreational use & $\begin{array}{l}\text { Tourist attractiveness of } \\
\text { vegetation }\end{array}$ \\
\hline $\begin{array}{l}\text { Querco roboris-Pinetum } \\
\text { Mixed pine-oak forest }\end{array}$ & High & Highly resistant & Very attractive \\
\hline $\begin{array}{l}\text { Potentillo albae-Quercetum } \\
\text { Thermophilous oak forest }\end{array}$ & High & Highly resistant & Very attractive \\
\hline $\begin{array}{c}\text { Leucobryo-Pinetum } \\
\text { Sub-Atlantic pine forest }\end{array}$ & \multirow{2}{*}{ High } & \multirow{2}{*}{ Quite resistant } & \multirow{2}{*}{ Very attractive } \\
\hline $\begin{array}{l}\text { Peucedano-Pinetum } \\
\text { Subcontinental pine forest }\end{array}$ & & & \\
\hline $\begin{array}{l}\text { Cladonio-Pinetum } \\
\text { Dry pine forest }\end{array}$ & High & $\begin{array}{c}\text { Sensitive } \\
\text { (walking indicated on designated roads) }\end{array}$ & Very attractive \\
\hline $\begin{array}{c}\text { Empetro nigri-Pinetum } \\
\text { Crowberry subatlantic pine forest }\end{array}$ & High & $\begin{array}{c}\text { Sensitive } \\
\text { (walking indicated on designated roads) }\end{array}$ & Very attractive \\
\hline $\begin{array}{l}\text { Molinio-Pinetum } \\
\text { Wet pine forest }\end{array}$ & High & $\begin{array}{l}\text { Sensitive (walking indicated on des- } \\
\text { ignated roads and even specially built } \\
\text { footbridges) }\end{array}$ & Attractive \\
\hline $\begin{array}{l}\text { Vaccinio uliginosi-Pinetum } \\
\text { Continental swamp pine forest }\end{array}$ & High & $\begin{array}{l}\text { Sensitive (walking possible on designated } \\
\text { roads and specially built footbridges) }\end{array}$ & Very attractive \\
\hline $\begin{array}{l}\text { Plagiothecio-Piceetum tatricum } \\
\text { Carpathian spruce forest }\end{array}$ & High & $\begin{array}{c}\text { Quite resistant } \\
\text { (walking indicated on designated trails) }\end{array}$ & Very attractive \\
\hline $\begin{array}{l}\text { Calamagrostio villosae-Piceetum } \\
\text { Sudetes spruce forest }\end{array}$ & High & $\begin{array}{l}\text { Quite resistant } \\
\text { (walking indicated on designated trails) }\end{array}$ & Very attractive \\
\hline $\begin{array}{l}\text { Abieti-Piceetum montanum } \\
\text { Fir-spruce forests }\end{array}$ & High & $\begin{array}{c}\text { Quite resistant } \\
\text { (walking indicated on designated trails) }\end{array}$ & Very attractive \\
\hline $\begin{array}{l}\text { Abietetum polonicum } \\
\text { Mixed fir forest }\end{array}$ & High & $\begin{array}{c}\text { Highly resistant } \\
\text { (walking indicated on designated trails) }\end{array}$ & Very attractive \\
\hline $\begin{array}{l}\text { Pinetum mughi carpaticum } \\
\text { Mountain pine forest }\end{array}$ & High & $\begin{array}{c}\text { Quite resistant } \\
\text { (walking indicated on designated trails) }\end{array}$ & Very attractive \\
\hline $\begin{array}{l}\text { Pinetum mughi sudeticum } \\
\text { Mountain pine forest }\end{array}$ & High & $\begin{array}{c}\text { Quite resistant } \\
\text { (walking indicated on designated trails) }\end{array}$ & Very attractive \\
\hline $\begin{array}{c}\text { Salici-Populetum } \\
\text { Willow-poplar riparian forest } \\
\text { (Salicetum albo-fragilis, Populetum albae) }\end{array}$ & High & $\begin{array}{l}\text { Highly resistant } \\
\text { (walking rather on designated roads } \\
\text { and specially built footbridges) }\end{array}$ & Very attractive \\
\hline $\begin{array}{l}\text { Fraxino-Alnetum } \\
\text { Alder-ash forest }\end{array}$ & high & $\begin{array}{c}\text { Highly resistant } \\
\text { (walking rather on designated roads) }\end{array}$ & Very attractive \\
\hline $\begin{array}{l}\text { Ficario-Ulmetum minoris } \\
\text { Elm-ash forest }\end{array}$ & High & $\begin{array}{c}\text { Highly resistant } \\
\text { (walking rather on designated roads) }\end{array}$ & Very attractive \\
\hline $\begin{array}{c}\text { Alnetea glutinosae } \\
\text { Alder forests } \\
\end{array}$ & \multirow{2}{*}{ High } & \multirow{2}{*}{$\begin{array}{c}\text { Sensitive } \\
\text { (walking possible on designated roads } \\
\text { and specially built footbridges) }\end{array}$} & \multirow{2}{*}{$\begin{array}{l}\text { Very attractive for people } \\
\text { who like swamp forests }\end{array}$} \\
\hline $\begin{array}{c}\text { (Ribeso nigri-Alnetum, } \\
\text { Sphagno squarrosi-Alnetum) }\end{array}$ & & & \\
\hline $\begin{array}{l}\text { Luzulo luzuloidis-Fagetum } \\
\text { Acidophilic mountain beech forest }\end{array}$ & High & $\begin{array}{c}\text { Quite resistant } \\
\text { (walking indicated on designated roads) }\end{array}$ & Very attractive \\
\hline $\begin{array}{l}\text { Luzulo pilosae-Fagetum } \\
\text { Acidophilic lowland beech }\end{array}$ & High & $\begin{array}{l}\text { Quite resistant } \\
\text { (walking indicated on designated roads) }\end{array}$ & Very attractive \\
\hline $\begin{array}{l}\text { Galio odorati-Fagetum } \\
\text { Lowland beech forest }\end{array}$ & high & $\begin{array}{c}\text { Highly resistant } \\
\text { (walking indicated on designated roads) }\end{array}$ & Very attractive \\
\hline $\begin{array}{l}\text { Cephalanthero-Fagenion } \\
\text { Orchid beech forest }\end{array}$ & High & $\begin{array}{c}\text { Highly resistant } \\
\text { (walking indicated on designated roads) }\end{array}$ & Very attractive \\
\hline $\begin{array}{l}\text { Dentario glandulosae-Fagetum } \\
\text { Carpathian beech forest }\end{array}$ & High & $\begin{array}{c}\text { Highly resistant } \\
\text { (walking indicated on designated trails) }\end{array}$ & Very attractive \\
\hline
\end{tabular}


Table 1. Continued.

\begin{tabular}{|c|c|c|c|}
\hline $\begin{array}{l}\text { Dentario enneaphylli-Fagetum } \\
\text { Sudetes beech forest }\end{array}$ & High & $\begin{array}{l}\text { Highly resistant } \\
\text { (walking indicated on designated trails) }\end{array}$ & Very attractive \\
\hline $\begin{array}{c}\text { Tilio cordate-Carpinetum } \\
\text { Subcontinental oak-hornbeam forest } \\
\text { and } \\
\text { Galio silvatici-Carpinetum } \\
\text { Sub-Atlantic oak-hornbeam forest }\end{array}$ & High & Highly resistant & Very attractive \\
\hline $\begin{array}{c}\text { Arrhenatheretalia elatioris } \\
\text { Fresh meadows }\end{array}$ & High & Highly resistant & Very attractive \\
\hline $\begin{array}{l}\text { Molinetalia caeruleae } \\
\text { Wet meadows }\end{array}$ & Medium & $\begin{array}{c}\text { Highly resistant } \\
\text { (walking rather on designated roads) }\end{array}$ & Very attractive \\
\hline $\begin{array}{l}\text { Lolio-Cynosuretum } \\
\text { Pastures }\end{array}$ & Medium & Highly resistant & Attractive \\
\hline $\begin{array}{l}\text { Festuco-Brometea } \\
\text { Xetotermic vegetation }\end{array}$ & Medium & Highly resistant & Very attractive \\
\hline Arable lands & Low & $\begin{array}{c}\text { Resistant } \\
\text { (walking on designated roads) }\end{array}$ & $\begin{array}{l}\text { Attractive for people who } \\
\text { like agricultural landscape }\end{array}$ \\
\hline $\begin{array}{l}\text { Synanthropical communities associated with } \\
\text { horticultural crops }\end{array}$ & Low & $\begin{array}{c}\text { Resistant } \\
\text { (walking on designated roads) }\end{array}$ & $\begin{array}{l}\text { Very attractive not only } \\
\text { for people who like agri- } \\
\text { cultural landscape }\end{array}$ \\
\hline $\begin{array}{l}\text { Mosaic of segetal communities in cultivated } \\
\text { areas }\end{array}$ & Low & $\begin{array}{c}\text { Resistant } \\
\text { (walking on designated roads) }\end{array}$ & $\begin{array}{l}\text { Attractive for people who } \\
\text { like agricultural landscape }\end{array}$ \\
\hline $\begin{array}{l}\text { Perennial plant communities in ruderal } \\
\text { habitats (Artemisietea vulgaris) }\end{array}$ & Low & Resistant & $\begin{array}{l}\text { Attractive for people who } \\
\text { like agricultural landscape }\end{array}$ \\
\hline $\begin{array}{l}\text { Segetal and ruderal communities } \\
\text { (Stellarietea mediae) }\end{array}$ & Low & Resistant & $\begin{array}{l}\text { Attractive for people who } \\
\text { like agricultural landscape }\end{array}$ \\
\hline
\end{tabular}

four categories of areas' landscape natural values in tourism aspect have been distinguished:

Category A - areas with very high natural landscape values in tourism aspect (spatial-landscape units obtained from 20 to 24 points in the assessment);

Category B - areas with high natural values in tourism aspect (unit score from 15 to 19 points);

Category $\mathbf{C}$ - areas with medium natural values in tourism aspect (from 9 to 14 points);

Category D - areas with relatively low natural values in tourism aspect ( $\leq 8$ points).

The maps were based on field researches and the Geographic Information System (PD GIS) with geographic coordinate system: ETRS_1989_Poland_ CS92, WKID: 2180 Authorization: ${ }^{-}$ESG $\bar{G}$ using Software: ArcGIS.

\section{Results and Discussion}

Based on the performed natural inventory in spatial-landscape units, it has been confirmed that forest communities dominate in the area of Otwock commune. Mixed forests (Querco roboris-Pinetum) and pine forests (Peucedano-Pinetum/LeucobryoPinetum) occur mainly in the central and southern parts of the commune on accumulated river sands/dunes of river sands. Riparian forests (Salici-Populetum and
Fraxino-Alnetum) occur in areas with flowing surface water and alder forests (Ribeso nigri-Alnetum) - on wet habitats with tendency to water stagnation, mainly in southern and northern parts of the study area. The willow and poplar riparian forests (Salici-Populetum) are located on the Vistula River on flood terraces of the valley. Along the Świder River, riparian forest (Fraxino-Alnetum) extends, while the alder forests (Ribeso nigri-Alnetum) are located in wetlands in rather small patches. In some places, on local elevations of terrain, there are also patches of luminous oak forests (Potentillo albae-Quercetum), but small and dispersed. A continental swamp forest (Vaccinio uliginosiPinetum) was identified in one place. Due to its value, it is protected as the "Pogorzelski Mszar" nature reserve. The next type of vegetation, covering a quite large part of the study area, are ruderal and synanthropic communities associated with urban and residential areas. Communities of perennial plants in ruderal habitats (Artemisietea vulgaris) are usually located in the development zone of the Otwock city. Other plant communities of ruderal character (Stellarietea mediae) are those associated with arable lands. They occupy the area of Otwock development mentioned above, specially accompanying housing estates. They form a transition zone between the areas of Artemisietea vulgaris communities and the mosaic of segetal communities of arable lands. Allotment gardens, which are located 


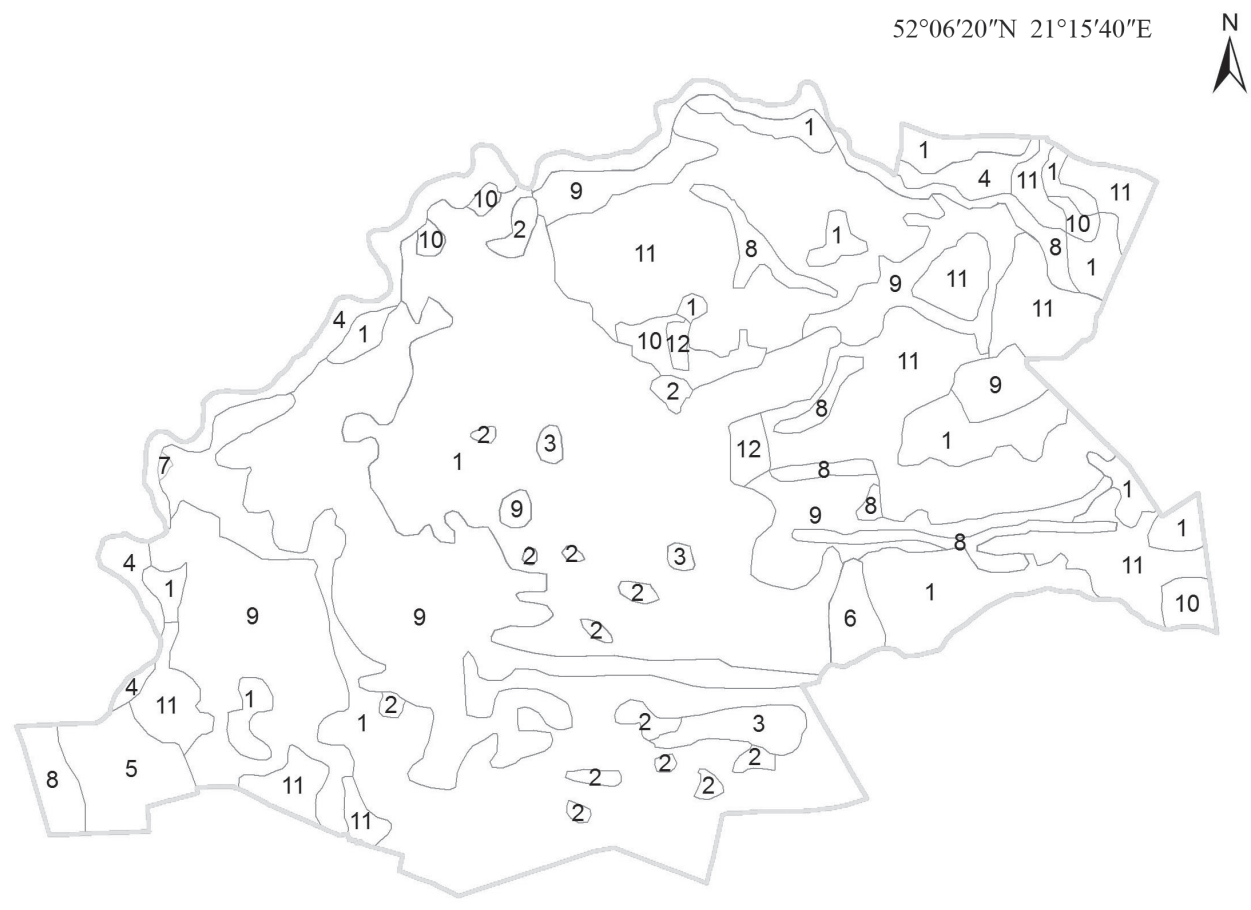

1 - Peucedano-Pinetum/Leucobryo-Pinetum, 2 - Querco roboris-Pinetum, 3 - Potentillo albae-Quercetum,

4 - Fraxino-Alnetum, 5 - Salici-Populetum and wet meadows Molinietalia, 6 - Vaccinio uliginosi-Pinetum,

7 - wet meadows Molinietalia, 8 - surface water and rushes/aquatic vegetation, 9 - Artemistiea vulgaris,

10 - Stellarietea mediae, 11 - mosaic of synanthropical vegetation and groups of trees/plantings,

12 - synanthropical vegetation typical for horticultural cultivation

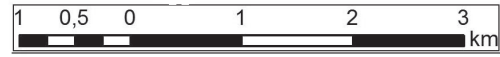

Fig. 4. Scheme of main types of existing vegetation in Otwock commune (original).

on the border zone of forests and agricultural areas, are covered mainly by synanthropic vegetation associated with horticultural cultivations. In some places, wet meadows are represented by Molinietalia caeruleae. These are semi-natural communities of meadows and pastures, occurring in periodically flooded and wet areas (Fig. 4).

The research area was divided into nineteen spatiallandscape units representing 9 types of them (numbers of units' types: from 1 to 9). The division was done basing on two main criteria: relief of terrain and vegetation cover/land use. Types of spatial-landscape units are represented by: riverbed of the Vistula River and areas with riparian forests and wet meadows (Type 1: spatial-landscape unit 1) single-family and multi-family development areas with accompanying greenery (type 2: spatial-landscape units $2 \mathrm{~A}$ and $2 \mathrm{~B}$ ); mixed forest areas with predominance of forest plots (type 3: spatial-landscape units 3A, 3B, 3C and 3D); coniferous forests (type 4: spatial-landscape units 4A, 4B and 4C); farm and family development areas with accompanying greenery (type 5: spatial-landscape units $5 \mathrm{~A}, 5 \mathrm{~B}$ and $5 \mathrm{C}$ ); area excluded from evaluation: Institute of Atomic Energy (type 6: spatial-landscape unit 6); mosaic of arable lands and mid-field plantings (type 7: spatial-landscape units 7A and 7B); mosaic of arable lands and coniferous forests (type 8: spatiallandscape units $8 \mathrm{~A}$ and $8 \mathrm{~B}$ ), aquatic vegetation of the Świder River with riparian forests by the river (type 9: spatial-landscape unit 9) (Fig. 5).

The whole vegetation is characterized by high resistance to recreational use in the area of Otwock commune, with the exception of alder and swamp forests. The degree of attractiveness of the plant cover is very diverse (Table 2, Fig. 6). In the study area there are 8 areas and 30 objects legally protected due to their natural value. The Mazowiecki Landscape Park with the buffer zone and the Warsaw Protected Landscape Area are in central and southern parts of the commune. Fragment of the Świder River Nature Reserve covers the entire Świder River within the administrative boundaries of the commune. The rare swamp forest is located in the Pogorzelski Mszar Nature Reserve. The first Natura 2000 Area (PLB140004) is located along the south-western border of the commune, on the Vistula River and covers the River and all forests and meadows on flooded terraces. The next Nature 2000 Area (PLB140025) includes the Świder River and forests, as well as nearby meadows, fields and tree stands. The ecological site called Pogorzelska Struga is located in the southern end of the commune area. The Warsaw Protected Landscape Area occupies the 


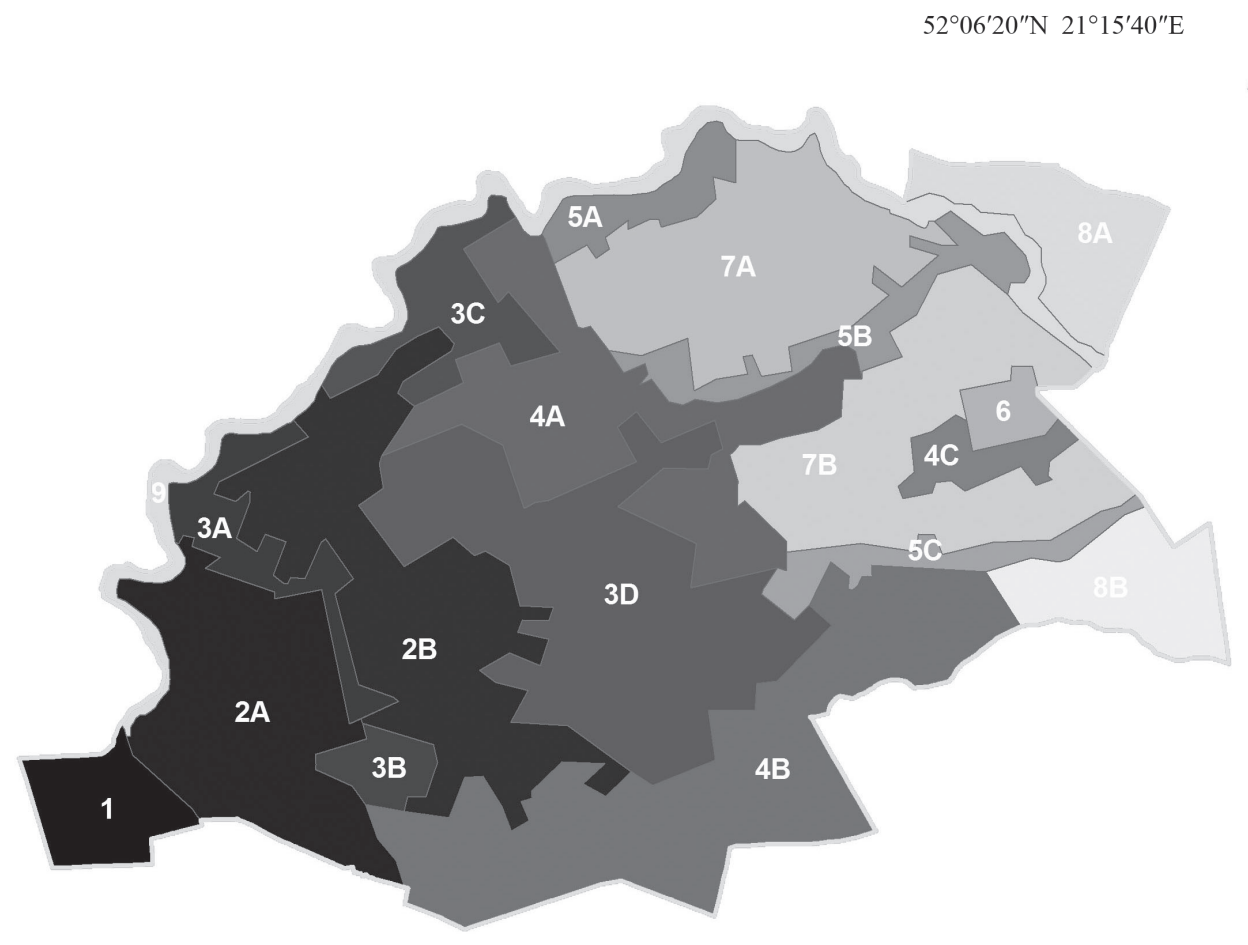

$\bigwedge^{N}$

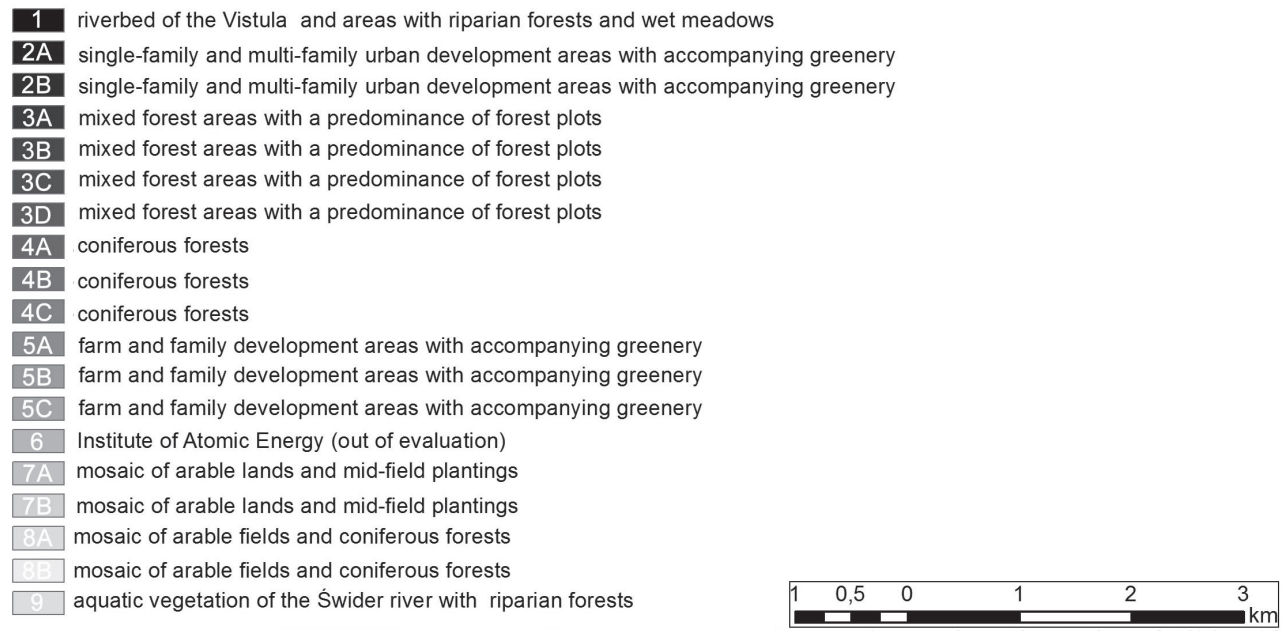

Fig. 5. Division of Otwock commune into spatial-landscape units with according to the landscape/land use types (original).

largest area among protected areas. Protected objects as monuments of nature are monumental trees occurring in places throughout the commune and the most numerous cluster occurs in the city center (Table 2 and Fig. 6).

As a result of the landscape natural values evaluation, two spatial-landscape units with very high natural values were identified (units No. 1 and 9), five spatial-landscape units with high natural values $(3 \mathrm{~A}, 3 \mathrm{C}$, $3 \mathrm{D}, 4 \mathrm{~A}, 4 \mathrm{~B})$, ten spatial-landscape units with medium natural values (units No. $2 \mathrm{~A}, 2 \mathrm{~B}, 3 \mathrm{~B}, 4 \mathrm{C}, 5 \mathrm{~A}, 5 \mathrm{~B}, 7 \mathrm{~A}, 7 \mathrm{~B}$, $8 \mathrm{~A}, 8 \mathrm{~B}$ ) and one spatial-landscape unit No. 5C with relatively low natural values. The spatial-landscape unit No. 6 was excluded from the assessment because of the location of the Atomic Energy Institute. High natural values in spatial-landscape units were determined by the type of vegetation, surface water occurrence, the presence and number of protected natural areas and objects as well the relief of terrain. The presence of plant communities with a high degree of naturalness and high resistance to tourist use proves the high value and suitability of the area for tourism. The presence of vegetation of high attractiveness for tourists, such as forests and waters, also influenced the research result. It is important to keep variety of the plant cover as a factor increasing tourist attractiveness, since the diversity of elements is more preferred by tourists [16]. Due to tourists' preference for the diversity of vegetation, agricultural and urban areas will also absorb 
some tourist movement. Thus, the most valuable natural areas will be partially relieved. In Owock, the highest assessment considered these units where three types of vegetation were: natural, semi-natural and synanthropic ones (Table 2, Fig. 6).

In the case of protected areas and protected objects (monuments of nature), their quantity and diversity were of significant importance in the overall assessment. Establishing legal protection is a confirmation of high natural values including vegetation and branding an area of high importance regarding tourism attractiveness (a good advertisement for an area). The highest rated were units with at least several nature monuments and three different protected areas, or one covering a significant part of the area. The proximity of water courses and water reservoirs as well diversification of land relief also increased the score in a given unit. Surface water, varied land relief and specific geological features are valuable elements of tourist interest in themselves as well affecting diversity of vegetation. In the presented assessment the lower natural values in some units were determined by a small variety of natural elements, a large degree of transformation of the flora and the lack of forms of nature protection. Summarizing, the spatial-landscape units with the highest natural values estimation were characterized by the diversity of vegetation, attractiveness of vegetation, protected areas, water surface occurrence and diversified land relief.

Natural resources management and environmental planning are increasingly being promoted globally as mechanisms to resolve intractable resource use problems and conflicts, there still remains no common theoretical base upon which such approaches are developed and implemented [19]. The concept of ecosystem services has been used as a tool for nature management and biodiversity conservation [7].

Vegetation is one of components of landscape [64], being directly and strongly exposed to the influence of tourism as well having the crucial meaning for this kind of activity. Furthermore, vegetation has the high diagnostic value in terms of environment state (perfect bioindicators: plant associations and species) and clearly reflects condition of the whole landscape. That is why our proposition of assessment analysis puts special emphasis on vegetation in different aspects, as: diversity, degree of naturalness, resistance to recreation use, attractiveness for tourists. For instance, high trampling may cause far-reaching changes in vegetation, such as species replacement and reduction in total plant cover [66].

The presented results showed relatively simple and effective approach to landscape natural values assessment, with special regard to vegetation and with the context of the whole landscape, which is helpful for landscape planning including tourism aspect. The analysis made it possible to prove and spatially indicate terrains of different natural values for tourist aspect in the study area, giving the image of area natural potential and guidelines to management. In Otwock commune, the existing types of natural values predestine area to develop such tourist activities as: qualified tourism, hiking, biking, cross-country skiing (lowland, but large terrain denivelations occur), crosscountry races, horseback riding, baths in the river,

Table 2. Results of landscape natural values evaluation, with special regard to vegetation, in terms of tourism in Otwock commune (original).

\begin{tabular}{|c|c|c|c|c|c|c|c|c|c|c|c|c|c|c|c|c|c|c|}
\hline \multirow{2}{*}{ Criteria of assessment } & \multicolumn{18}{|c|}{ Numbers/codes of spatial-landscape units and assessment in points ${ }^{*}$} \\
\hline & 1 & $2 \mathrm{~A}$ & 2B & $3 \mathrm{~A}$ & $3 \mathrm{~B}$ & $3 \mathrm{C}$ & $3 \mathrm{D}$ & $4 \mathrm{~A}$ & 4B & $4 \mathrm{C}$ & $5 \mathrm{~A}$ & $5 \mathrm{~B}$ & $5 \mathrm{C}$ & 7A & 7B & $8 \mathrm{~A}$ & $8 \mathrm{~B}$ & 9 \\
\hline Protected areas occurring & 3 & 2 & 1 & 2 & 1 & 2 & 2 & 2 & 3 & 0 & 1 & 1 & 1 & 2 & 0 & 3 & 3 & 3 \\
\hline Protected objects occurring & 3 & 1 & 2 & 2 & 1 & 0 & 2 & 2 & 3 & 0 & 1 & 1 & 1 & 2 & 1 & 0 & 1 & 1 \\
\hline $\begin{array}{c}\text { The degree of naturalness of the } \\
\text { vegetation }\end{array}$ & 3 & 1 & 1 & 2 & 2 & 2 & 2 & 2 & 2 & 2 & 1 & 1 & 1 & 1 & 1 & 2 & 2 & 3 \\
\hline $\begin{array}{l}\text { Plant communities resistant to } \\
\text { recreational use }\end{array}$ & 1 & 3 & 3 & 3 & 3 & 3 & 3 & 2 & 2 & 2 & 2 & 2 & 2 & 2 & 2 & 2 & 2 & 2 \\
\hline $\begin{array}{c}\text { Attractiveness of plant } \\
\text { communities -tourism aspect }\end{array}$ & 3 & 1 & 1 & 2 & 2 & 2 & 2 & 2 & 2 & 2 & 1 & 1 & 1 & 2 & 2 & 2 & 3 & 3 \\
\hline Diversity of vegetation & 3 & 1 & 1 & 2 & 2 & 2 & 2 & 2 & 2 & 2 & 1 & 1 & 1 & 2 & 2 & 2 & 2 & 3 \\
\hline Surface waters occurring & 3 & 2 & 2 & 2 & 0 & 2 & 0 & 2 & 0 & 0 & 1 & 1 & 0 & 2 & 2 & 1 & 0 & 3 \\
\hline Land relief & 3 & 2 & 2 & 1 & 1 & 2 & 2 & 2 & 2 & 2 & 1 & 1 & 1 & 1 & 1 & 2 & 1 & 2 \\
\hline Sum & 22 & 13 & 13 & 16 & 12 & 15 & 15 & 16 & 16 & 10 & 9 & 9 & 8 & 14 & 11 & 14 & 14 & 20 \\
\hline $\begin{array}{l}\text { Category } \\
\text { of value }\end{array}$ & A & $\mathrm{C}$ & $\mathrm{C}$ & B & $\mathrm{C}$ & B & B & B & B & $\mathrm{C}$ & $\mathrm{C}$ & $\mathrm{C}$ & $\mathrm{D}$ & $\mathrm{C}$ & $\mathrm{C}$ & $\mathrm{C}$ & $\mathrm{C}$ & A \\
\hline
\end{tabular}

*) Spatial-landscape unit No. 6 was not under assessment - the closed area of the Institute of Atomic Energy 


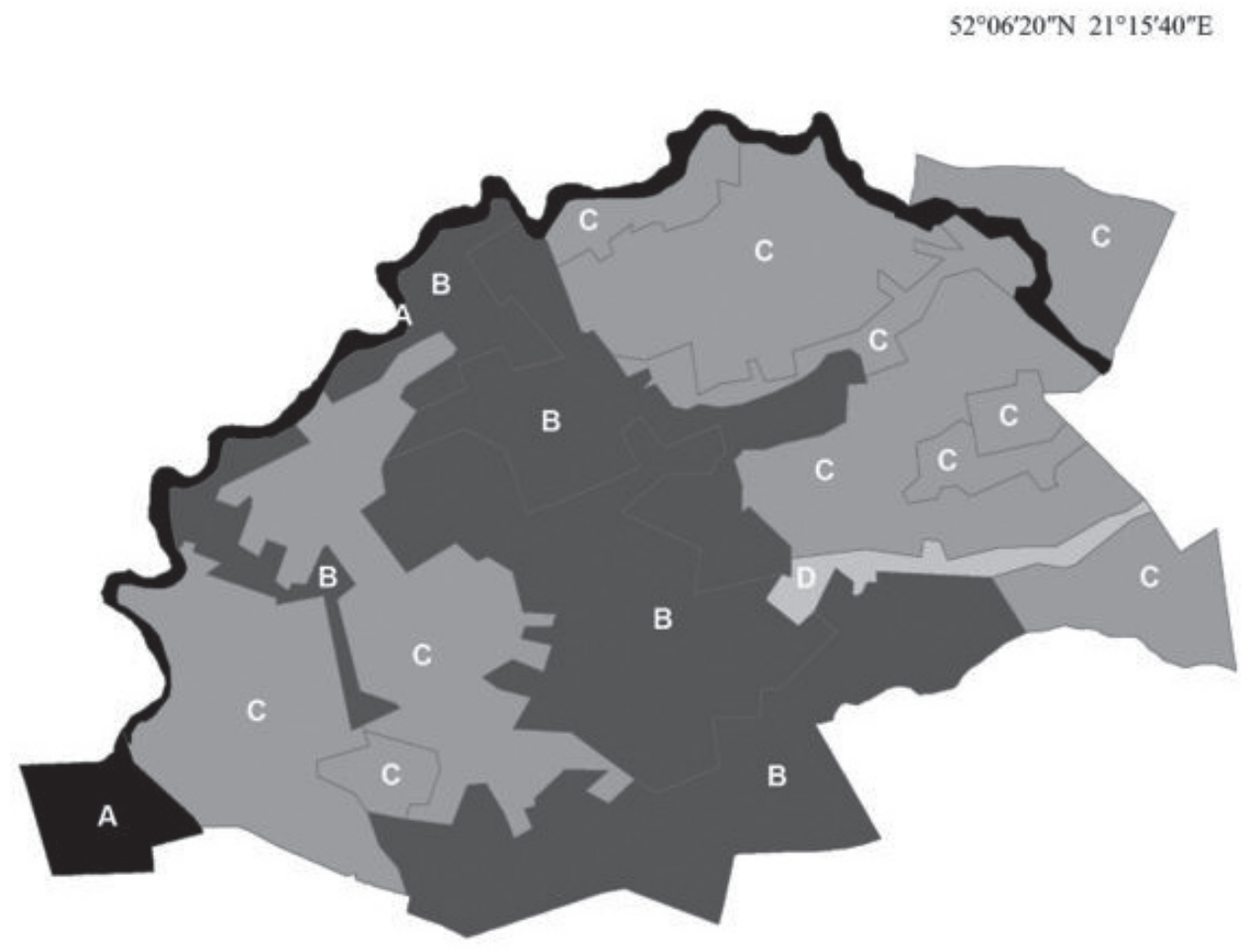

i

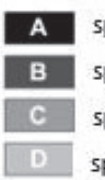

spatial-landscape units (areas) with very high natural values for tourism aspect

spatial-landscape units (areas) with high natural values for toursim aspect

spatial-landscape units (areas) with medium natural values for tourism aspect

spatial-landscape units (areas) with relatively low natural values for tourism aspect

\begin{tabular}{llllll}
\hline & 0,5 & 0 & 1 & 2 & 3 \\
\hline & & &
\end{tabular}

Fig. 6. Results of landscape natural values evaluation, with special regard to vegetation, in Otwock commune (original).

canoeing (the Świder River), sunbathing on sandy or grassy beaches, ecological education, tourism related with health treatment (spa facilities and health service infrastructure) and "slow" tourism.

In the Authors' opinion, an important thing is to keep relationship and balance between condition and quality of vegetation (which reflects the condition of full landscape), tourism and human well-being. There is a specially strong potential in areas of protected nature, as regards tourism development - a symbiotic relationship between tourism and natural conservation. It is necessary that local/regional authorities undertake greater effort to give more brand to protected areas to make them branded products to tourists. In the study area, there is many protected areas of different range and character in the study area and its vicinity. They are very attractive for tourists and give the chance of greater development basing on balance between natural values conservation and tourist use, generating bigger income of local population and authorities. At times, tourism may be actually one of the main economic justifications for protection of these areas [67, 68]. The protected areas should have elaborated programs of sustainable tourism development. The frame of tourist accessibility (tourism program) is included in obligatory document: protection plan, which is prepared for 20 years period [9]. Such planes give possibility to control tourist movement and simultaneously allow to gain benefits from tourism [58]. In Poland, protection plans are obligatory for national parks, nature reserves, landscape parks and Nature 2000 areas. Some of these protection forms (natural reserves, landscape park and Nature 2000 area) occur in Otwock commune and have formulated directions for tourism development.

Otwock commune has got the big potential for developing sustainable and smart tourism [70] because of the attractiveness and usefulness of vegetation values, diversity of terrain relief and surface water occurring. Accommodation and sanitary facilities (next to natural and cultural values) determine development of tourism function and types of tourism [71]. Otwock commune have got significant accommodation for shortstay and long-stay for tourists [60, 69]. The concept of sustainable tourism should be applied to every area and every form of tourism, providing the pursuit to goals of sustainable development. The concept of "slow" tourism 
is compatible with sustainable tourism. The "fast" life in developed countries results in searching for relaxation and peace, which is reflected in cultivating new forms of tourism closer to nature. "Slow" tourism is a part of the concept of sustainable tourism, because it favors the achievement of economic, social and environmental goals. Practicing "slow" tourism does not exclude developing other forms of tourism. Thanks to this, towns and regions, that host tourists, can develop the infrastructure, but keep principles of sustainable development [45]. The idea of "slow" tourism is closer to such forms of tourism, as: ecotourism, responsible tourism and active tourism. An important thing in development of ecotourism is preparation of infrastructure for "green tourism" including, for example, eco-trails. That is, why local governments should finance and promote this sector of tourism [2, 17, 72, 73]. Additionally, thinking of "active" tourism one should mention: cycling, canoeing, horse riding and others. These tourist activities are preferred because of care of slower pace of life or human health (physical and mental), balanced development, respect for the tradition of the visited place and interest in learning about the world in details.

Otwock commune is a very good region to combine "slow" tourism and ecotourism. Slow tourism is one of the possibilities for this region, where tourists spend at least one week in one place and rent a room or apartment instead of a hotel. The second characteristic element is visiting the closest area and getting to know all the attractions and features (explore all secrets) of the visited region [45]. The occurrence of vegetation relatively resistant to trampling and diversified rural landscapes (forests, meadows, arable lands in mosaic layout, rivers of natural character, villages) in Otwock commune have potential to develop agrotourism as well. Tracks and bicycle routes as well as a canoeing (on the Świder River) are also sample opportunities to get the interest of users involved, with low impact on vegetation. Local authorities should put particular attention to proper use of the commune's values and improvement of conditions for recreation/tourism synchronizing them with economic development. Moreover, it would be of great benefit: the more ecotourism development as a contributing factor to nature conservation and sustainable development. All forms: ecotourism, agritourism, "slow" tourism and the like will also support local services and products (e.g. production of traditional souvenirs, preparation of local food, traditional culture as folk customs, folk dances etc.). In the presented paper, methodic approach, used criteria of assessment correspond well with forms of tourism mentioned above and recommended to lead to sustainable development in rural areas. Such combination of evaluation criteria and partly system of scoring have been not presented by other authors. It is necessary to promote eco-friendly forms of tourism and keep the high biodiversity not only in existing protected areas, but in the whole area, including terrains with vegetation vulnerable to tourist use, but often very attractive also in visual aspects. Furthermore, the presented approach to landscape natural values in the aspect of tourism allows to get closer towards positive correlation between tourist use and high biodiversity. It is proposed to design/use proper facilities for tourists, for example footbridges or view towers, preferably in combination with ecological/landscape education. Sustainable landscapes are no fiction, if the landscape qualities are well defined [59] and the balance is between natural values and land use/land management.

\section{Conclusions}

Planning of tourist function in an area should be preceded by landscape natural values assessment to keep balance between tourist use and quality of natural/ landscape values.

There are several possible ways to assess landscape resources, referenced in the paper. Criteria and way of evaluation depend on the purpose of assessment (e.g. tourism and biodiversity together) and specificity of landscape/nature in a study area. Presented original methodical approach to landscape natural values assessment in the aspect of tourism, applied and tested in Otwock area at local level of management, is one of possible method to use.

The presented landscape natural values assessment, with special regard to vegetation as the highly effective indicator of environment condition, is original. The assumed combination of used evaluation criteria and partly system of awarding points have been not presented in such order yet. The set of criteria selected in this way helps to positively correlate tourist use with high biodiversity. The application of such research stages, as: field research, mapping of vegetation and other distinguishing natural elements/features, division of the study area into spatial-landscape units, selection of criteria of assessment and system of evaluation, conducting an assessment, classification of landscape values into categories and formulating guidelines to management including tourist use, leads to clear and reliable results, as the case study of Otwock proves it.

The set of evaluation criteria used in presented approach is very universal, however addressed mainly to local level of management. The used criteria are relatively easy to apply and helpful for landscape planners and decisions makers about tourism and other functions. Furthermore, such methodical approach may be especially convenient in the areas where values of inanimate nature are not highly spectacular and/or information on vegetation is more detailed and also authorities want to do this study on their own with a limited number of experts.

The assessment of landscape natural resources for tourism aspect through the prism of vegetation is an interesting and affective approach, because vegetation has the high bioindication value, reflects well the 
condition of the whole environment and is strictly combined with tourist use and tourist attractiveness.

The presented characteristic of main types of vegetation for areas in Central Europe in terms of resistance to tourist use and tourist attractiveness may be a set of guidelines for decision makers dealing with development and environment.

Methodical approach and obtained research results were understandable for a wide range of officials and specialists in Otwock commune. The research results confirmed high quality of natural values in the study area. The study area is predestined to tourism development, especially of eco-friendly forms, as: sustainable tourism, ecotourism, "slow" tourism, agritourism and qualified tourism, with predomination of tourist activities of low impact on environment.

\section{Acknowledgments}

The research was carried out in 2019-2020 from the funds of the Ministry of Science and Higher Education to maintain the research potential. The authors would like to thank the anonymous Reviewers for their comments improving the quality of this paper.

\section{Conflict of Interest}

The Authors declare no conflict of interest.

\section{References}

1. AN L.T., MARKOWSKI J., BARTOS M., RZENCA A., NAMIECINSKI P. An evaluation of destination attractiveness for nature-based tourism: Recommendations for the management of national parks in Vietnam. Nature Conservation, 32: 51-80, https://doi.org/10.3897/ natureconservation.32.30753. 2019.

2. POLAT Z., DEMIREL Ö. Sustainable landscape planning. Evaluation of alternative tourism in the light of natural cultural and visual resources in Turkey landscape. Journal of Environmental Protection and Ecology, 17 (3), 1220, 2016.

3. ASMELASH A.S, KUMAR S. Assessing progress of tourism sustainability: Developing and validating sustainability indicators. Tourism Management, 71, 67, 2019.

4. GHERMANDI A., CAMACHO-VALDEZ V., TREJOESPINOSA H. Social media-based analysis of cultural ecosystem services and heritage tourism in a coastal region of Mexico. Tourism Management, 77, https://doi. org/10.1016/j.tourman.2019.104002, 2020.

5. PREVOLŠEK B., MAKSIMOVIĆ A., PUŠKA A., PAŽEK K., ŽIBERT M., ROZMAN Č. Sustainable Development of Ethno-Villages in Bosnia and Herzegovina - A Multi Criteria Assessment Sustainability, 12 (4), 1399, https://doi. org/10.3390/su12041399, 2020.

6. The Travel \& Tourism Economic Impact, World Travel and Tourism Council, online: https://dossierturismo.files. worldpress.com/2018/03/wttc-global-economic-impactand-issues-2.pdf, access 21.09.2020, 2018.

7. KULCZYK S., WOŹNIAK E., KOWALCZYK M. DEREK M. Ecosystem services in tourism and recreation. Revisiting the classification problem. Economics and Environment, 4 (51), 84, 2014.

8. JADHAV A., ANDERSON S., DYER M.J.B., SUTTON P.C. Revisiting Ecosystem Services: Assessment and Valuation as Starting Points for Environmental Politics https://dx.doi.org/10.3390/su9101755, 2017.

9. Nature Conservation Act 2004, consolidated act Journal of Laws of 2020, item 55 (with amendments) [In Polish], online: https://prawo.sejm.gov.pl, access 12.02.2021

10. SADOWSKI A., WOJCIESZAK M.M. Geographic differentiation of agritourism activities in Poland vs. cultural and natural attractiveness of destinations at district level. PLoS One. 14 (9): e0222576. DOI: 10.1371/ journal.pone.0222576, 2019.

11. MADIĆ A. Nature-based solutions for sustainable tourism development in protected natural areas: a review. Environment Systems and Decisions, 39, 249, 2019.

12. World Tourism Organization (UNWTO). Glossary of tourism terms. Online: www.unwto.org/glossary-tourismterms, access 20.08.2020.

13. Strategy for the sustainable development of tourism in the Otwock city for years 2012-2022, Otwock City Hall (project), online: www.archiwumbip.otwock.pl/sesje/ projekty, access 30.08.2020, 2011 [In Polish]

14. TRIBOT A.S., DETER J., MOUQUET N. Integrating the aesthetic value of landscapes and biological diversity. Proceedings of the Royal Society B. Biological Sciences, https://doi.org/10.1098/rspb.2018.0971, 2018.

15. GETZNER M., MEYERHOFF J. The Benefits of Local Forest Recreation in Austria and Its Dependence on Naturalness and Quietude. Forests, 11 (3), 326; https://doi. $\operatorname{org} / 10.3390 / \mathrm{f} 11030326,2020$.

16. KRZYMOWSKA-KOSTROWICKA A. Development and tourist traffic. Geographic Works, 147, 1988 [In Polish].

17. LEE T.H., JAN F.H. Development and validation of the ecotourism behavior scale. International Journal of Tourism Research, 20 (2), 191, https://doi:10.1002/jtr.2172, 2018.

18. IUCN-WCPA (World Commission on Protected Areas).. Protected Areas: Benefits beyond Boundaries -WCPA in Action. Gland: IUCN. 2000.

19. SATTI H.A., SULIEMAN H., YOUNG H., RADDAY A. Natural Resources Management: Local Perspectives from North and Central Darfur, ic.tufts.edu, 2020.

20. SOLECKA I. The use of landscape value assessment in spatial planning and sustainable land management - a review. Landscape Research, 44 (8), 966; https://doi.org/10. 1080/01426397.2018.1520206, 2019.

21. NOR A.N.M., ISNORM R.A., ABAS M.A., MALEK N.H.A, HASSIN N.H., AZIZ H.A., OMAR A.A.S., RAFAAI M.N.H. Landscape ecological assessment of potential ecotourism in Malaysia. International Journal of Civil Engineering and Technology (IJCIET), 9 (10), 969, 2018.

22. JOKIMAKI J. Urbanization and species occupancy frequency distribution patterns in core zone areas of European towns. European Journal of Ecology, 2 (2), 23, 2017.

23. PATRA S., SAHOO S., MISHRA P., MAHAPATRA S.C. Impacts of urbanization on land use cover changes and its probable implications on local climate and groundwater level. Journal of Urban and Management, 7 (2), 70, 2018. 
24. ŻARSKA B., FORNAL-PIENIAK B., ZARAŚJANUSZKIEWICZ E. Landscape protection and planning: Selected issues. SGGW [WULS Press], Warszawa, 238, 2014.

25. 25. HAVAS J., SAITO O., HANAKI K., TANAKA T. Perceived landscape values in the Ogasawara Islands. Ecosystem Services, 18, 130, 2016.

26. HAVAS J., SAITO O., HANAKI K., TANAKA T. Perceived landscape values in the Ogasawara Islands. Ecosystem Services, 18, 130, 2016.

27. BOGDANOWSKI J. The method of architectural and landscape units (JARK-WARK) in studios and design. In: New ideas and development of the field of landscape architecture in Poland. Wolski P. (ed.), $3^{\text {rd }}$ Forum of Landscape Architecture. SGGW, Warszawa, 58-71, 2000 [In Polish].

28. WEJCHERT K. Elements of urban composition. Arkady, Warszawa, 1984 [In Polish].

29. ŻARSKA B. Method of landscape meaning assessment of landscape dominant and conception of landscape dominant trails system. Ann. Warsaw Agricult. Univ.-SGGW, Horticult. Landsc. Architect, 23, 155, 2003.

30. SKALSKI J.A. Perceptual analysis of the landscape as a creative activity initiating the design process. SGGW, Warszawa, 2007 [In Polish].

31. BRODOWSKA-FARAG A. A new method of assessing the state of cultural values of the visual aspect of the village landscape. In: Sustainability and effectiveness of nature protection in Polish national parks. Andrzejewska A., Lubański A. (ed.), Kampinoski National Park, Izabelin, 81, 2009 [In Polish].

32. CHISHTI M.Z., ULLAH S., OZTURK I., USMAN A. Examining the asymmetric effects of globalization and tourism on pollution emissions in South Asia Environmental Science and Pollution Research, 27, 27721, 2020.

33. CONTEIRO M., CÓRDOVA-TAPIA F., BRAZEIRO A. Tourism impact assessment: A tool to evaluation the Environmental impacts of touristic activities in Natural Protected Areas. Tourism Management Perspectives, 28, 220, 2018.

34. WHINAM J., CHILCOTT N.M. Impacts after four years of experimental trampling on alpine/subalpine environments in western Tasmania. Journal of Environmental Management, 67, 339, 2003.

35. VALLEY M., APOLLO M., ANDREYCHOUK V. Trampling Intensity and Vegetation Response and Recovery according to Altitude: An Experimental Study from the Himalayan. Resources, 9, 98; doi:10.3390/ resources9080098, 2020.

36. JAHANI A., GOSHTASB H., SAFFARIHA M. Tourism impact assessment modelling of vegetation density for protected areas using data mining techniques. Land Degradation and Development, 31, 1502, 2020.

37. GISP. The Global Invasive Species Programme, https:// www.gisp.org, access: 12.01.2020, 2006.

38. THRELFALL C.G., WILLIAMS N.S.G., HANHS A.K., LIVESLEY S.J. Approaches to urban vegetation managemeant and the impacts on urban bird and bat assemblages. Landsc. Urban Plan., 153, 28, 2016.

39. PETŘÍK P., FATNA J., PETRÝL M. It is time to change land use and landscape management in the Czech Republic. Ecosystem Health and Sustainability. Special Feature: Ecosystem Management in Transition in Central and Eastern Europe. https://doi.org/10.1890/15-0016.1, 2015.
40. BRYANN B.A., NOLAN M., MCKELLAR L., CONNOR J.D., NEWTH D., HARWOOD T., KING D., NAVARRO J., CAI Y., GAO L., GRUNDY M., GRAHAM P., ERNST A., DUNSTALL S., STOCK F., BRINSMEAD T., HARMA I., GRIGG N.J., HATFIELD-DODDS S. Landuse and sustainability under intersecting global change and domestic policy scenarios: Trajectories for Australia to 2050. Global Environmental Change 38, 130-152, 2016.

41. LIU Y. Introduction to land use and rural sustainability in China. Land Use Policy, 74, 1-4

42. VINAYA KUMARA K.S., BINOY T.A. Eco-Tourism for Natural and Cultural Heritage Protection - A Study on Kudremukha National Park. Asia Pacific Journal of Research, 1, 24, 2017.

43. VALLS J.F., MOTA L., VIEIRA S.C.F., SANTOS R. Opportunities for Slow Tourism in Madeira. Sustainability, 11 (17), 4534, https://doi.org/10.3390/su11174534, 2019.

44. ÖZDEMIR G., ÇELEBI D. Exploring dimensions of slow tourism motivation. Anatolia. An International Journal of Tourism and Hospitality Research, 29, 540, 2018.

45. CIOLAC R., ADAMOV T., CIOLAC R., POPESCU G., LILE R., RUJESCU C., MARIN D. Agritourism - A Sustainable Development Factor for Improving the 'Health' of Rural Settlements. Case Study Apuseni Mountains Area. Sustainability, 11, 1467, 2019.

46. VAN SANDT A., LOW S.A., THILMANY D. Exploring Regional Patterns of Agritourism in the U.S.: What's Driving Clusters of Enterprises? Agric. Resour. Econ. Rev., 47, 592, 2018.

47. VAN DER BIEST K., MEIRE P., SCHELLEKENS T., D'HONDT B., BONTE D., VANAGT T., YSEBAERT T. Aligning biodiversity conservation and ecosystem services in spatial planning: Focus on ecosystem processes. Sci. Total Environ., 712, 136350, 2020.

48. CHRASTINA P., HRONCEK P., GREGOROVÁ B., ŽONCOVÁ M. Land-Use Changes of Historical Rural Landscape - Heritage, Protection, and Sustainable Ecotourism: Case Study of Slovak Exclave Č́v (Piliscsév) in Komárom-Esztergom County (Hungary). Sustainability, 12, 6048; doi:10.3390/su12156048, 2020.

49. GARCÍA M.A., YAGÜE J.L., DE NICOLÁS V.L., DÍAZPUENTE J.M. Characterization of Globally Important Agricultural Heritage Systems (GIAHS) in Europe. Sustainability, 12, 1611, 2020.

50. KIEFFER M. Community Rural Tourism and collective organization: a comparative approach in Mexico. Revista de Turismo y Patrimonio Cultural, 16 (2), 429, 2018.

51. SALVATORE AMMIRATO S., FELICETTI A.M., RASO C., PANSERA B.A., VIOLI A. Agritourism and Sustainability: What We Can Learn from a Systematic Literature Review. Sustainability, 12, 9575; doi:10.3390/ su1222957, 2020.

52. LISIAK M., BOROWIAK K., MUŃKO E. The concept of sustainable tourism development in rural areas - A case study of Zbąszyń commune. Journal of Water and Land Development, 32 (I-III), 63, 2017.

53. SANTORO A., VENTURI M., AGNOLETTI M. Agricultural Heritage Systems and Landscape Perception among Tourists. The Case of Lamole, Chianti (Italy). Sustainability, 12, 3509; doi:10.3390/su12093509, 2020.

54. ŠPULEROVÁ J., PEROVIČ F., MEDERLY P., MOJSES M., IZAKOVIČOVÁ Z. Contribution of traditional farming to ecosystem services provision: Case studies from Slovakia. Land, 7, 1, 2018.

55. KELLER R., CLIVAZ M., REYNARD E., BACKHAUS N. Increasing Landscape Appreciation through the 
Landscape Services Approach. A Case Study from Switzerland. Sustainability, 11, 5826, 2019.

56. VALDIVIA C., BARBIERI C. Agritourism as a sustainable adaptation strategy to climate change in the Andean Altiplano. Tourism Management Perspectives, 11, 18, 2014.

57. WOJCIECHOWSKA J. A summary assessment of the Agritourism Experience in Poland. PASOS 12. 565-579, 2014.

58. OLEŚNIEWICZ P., PYTEL S., MARKIEWICZPATKOWSKA J., SZROMEK A.R., JANDOVÁ S.A. Model of the Sustainable Management of the Natural Environment in National Parks - A Case Study of National Parks in Poland. Sustainability, 12, 2704, https://doi. org/10.3390/su12072704, 2020.

59. ABAH G.O., ONAH S.O. Striking an Interactive Balance Between Nature and Culture in Human Developmental Exploits for Sustainable Environmental Protection and Management. Global Journal of Health Science, 12 (5) 110; Published by Canadian Center of Science and Education, 2020.

60. AJDACKI P. Suburb of Warsaw. PTTK Otwock, 2007 [In Polish].

61. Program of Environment Protection for Otwock City for 2012-2015 with perspective 2016-2019. Otwock, online: otwock.pl/download/pos-2012-2015-1461935274.pdf, access 10.01.2020, 2013.

62. Strategy for the sustainable development of tourism in the Otwock city for years 2012-2022, Otwock City Hall (project), online: www.archiwumbip.otwock.pl/sesje/ projekty, access 30.08.2020, 2011 [In Polish]

63. ŻARSKA B. Study of landscape protection - methodics of working out for different areas. Annals of Warsaw Agricultural University - SGGW, Horticulture and Landscape Architecture 22, 111, 2001.
64. MATUSZKIEWICZ W. Guide to the determination of Polish plant communities, PWN, Warszawa, 2017 [In Polish].

65. WYSOCKI C., SIKORSKI P. Phytosociology used in landscape protection and shaping. SGGW, Warsaw, 2014.

66. WOLF I.D., CROFT D.B., GREEN R.J. Review Nature Conservation and Nature-Based Tourism: A Paradox? Environments, 6, 104; doi:10.3390/environments6090104, 2019.

67. JHA-THAKUR U., KHOSRAVI F., QUATTRONE G., BANDYOPADHYAY S., MAGEDERA I., GARIKIPATI S. Exploring the role of strategic environmental assessment in cultural heritage tourism planning: a case study of the Srirangapatna-Mysore region in India. Impact Assessment and Project Appraisal, https://doi.org./10.1080/ 14615517.2020.1841595, 2020.

68. ÇAY R.D., TAŞLI T.C. Determination of Recreation and Tourism Use Value of Bozcaada by Travel Cost Analysis Methods Polish Journal of Environmental Studies 30, (1) 35, 2021.

69. Environmental protection program for the Otwock poviat for 2019-2022 with a perspective until 2026 pdf, access: 15.01.2021, 2018

70. HABEEB N.J., WELI S.T. Relationship of Smart Cities and Smart Tourism: An Overview. HighTech and Innovation Journal 1 (4), 194, 2020.

71. FLORIČIĆ T. Sustainable Solutions in the Hospitality Industry and Competitiveness Context of "Green Hotels". Civil Engineering Journal 6 (6), 1104, 2020.

72. FORNAL-PIENIAK B., DŁUGOŃKI A. Landscape valuation for planning ecotourism trails - case study. Annals of Warsaw University of Life Sciences - SGGW Land Reclamation, 50 (3), 251, 2018.

73. IUCN-WCPA Protected Areas: Benefits beyond Boundaries - WCPA in Action. International Union for Conservation of Nature, Gland, 2000. 